the chances of success of overseas graduates at the MRCPsych exam:

(1) There should be access to videotaped interviewing skills teaching, as well as access to a mock examination, with videotaping where appropriate. The Working Party believe this to be the most important recommendation.

(2) Psychiatric tutors should strongly encourage failed candidates to apply for feedback and provide advice and counselling regarding examination failure. Where a candidate is very unlikely to succed at the exam, he or she should be given advice to that effect as early as possible.

(3) An opting out rather than opting in scheme for feedback, which would otherwise be automatic after a third failure, might overcome the reticence of candidates in applying for feedback.

REFERENCE

${ }^{1}$ Cox, J. L. \& BhaTe, S. (1983) Overseas Trainees in Psychiatry. Leaflet available from Overseas Trainees' Sub-Committee, Royal College of Psychiatrists.

\title{
Overseas Graduates and the MRCPsych
}

\section{R. H. CAWLEY, Chief Examiner}

Between 1977 and 1984 the pass rates for the Preliminary Test for UK/Eire candidates varied between $64 \%$ and $84 \%$ whilst those for overseas candidates were in the range $23 \%$ to $42 \%$. Corresponding figures for the Membership Examination were $61 \%$ to $70 \%$ and $25 \%$ to $43 \%$ respectively. During those years overseas candidates were in the majority, comprising $60-65 \%$ of those taking the Preliminary Test and $50-55 \%$ of those taking the Membership Examination. Over the last two years the proportions have fallen to $40-50 \%$.

This paper presents: (i) a detailed analysis of the results of one Preliminary Test (September 1984) and one Membership Examination (November 1984); and (ii) a comparison of parallel cohorts of home and overseas candidates

TABLE I

Medical schools of graduation of candidates

\begin{tabular}{|c|c|c|c|}
\hline $\begin{array}{l}\text { Graduated in medical } \\
\text { schools in: }\end{array}$ & & \multicolumn{2}{|c|}{$\begin{array}{c}\text { Number of } \\
\text { candidates }(\%)\end{array}$} \\
\hline \multicolumn{4}{|l|}{ A. Preliminary Test: September 1984} \\
\hline UK/Eire & & 191 & $(52)$ \\
\hline Indian Sub-Continent & & 114 & (31) \\
\hline United Arab Republic & & 16 & \\
\hline Europe & & 15 & \\
\hline Far East & & 13 & (17) \\
\hline Africa & & 10 & \\
\hline N. America, Australasia & & 9 & \\
\hline & Total & $\overline{368}$ & \\
\hline \multicolumn{4}{|c|}{ B. Membership Examination: November 1984} \\
\hline UK/Eire & & 198 & $(55)$ \\
\hline Indian Sub-Continent & & 97 & $(27)$ \\
\hline United Arab Republic & & 21 & \\
\hline Europe & & 15 & \\
\hline Far East & & 7 & (19) \\
\hline Africa & & 15 & \\
\hline N. America, Australasia & & 9 & \\
\hline & Total & $\overline{362}$ & \\
\hline
\end{tabular}

who made their first attempts at the Membership in 1974-79.

\section{The Autumn 1984 Examinations}

As always the largest numbers of overseas candidates came from the Indian Sub-Continent (Table 1). Hassall and Trethowan grouped the Arabs with the Indians in their analysis, ${ }^{1}$ but examination of current figures suggests that it is now more appropriate to compare the three main subgroups of candidates according to whether their basic medical qualification was in the UK or Eire, in the Indian Sub-Continent, or elsewhere. UK/Eire trainees fare best and the Indians worst with the others from overseas taking an intermediate position (Table II).

Number of attempts

Of the candidates in the Preliminary Test, $64 \%$ were making their first attempt, $18 \%$ second, and $18 \%$ third and subsequent attempts. Corresponding figures for the

TABLE II

Pass rates among British and Overseas candidates

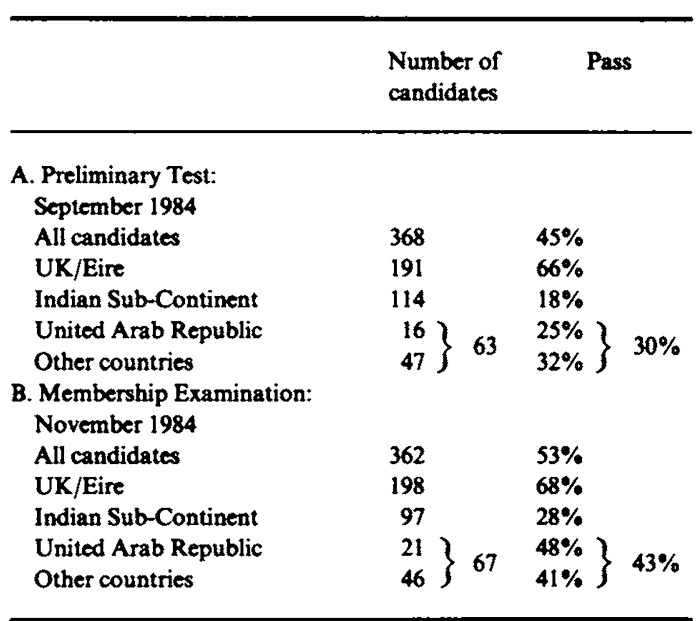


Membership Examination were $59 \%$ first attempters, $13 \%$ second and $21 \%$ third. The proportions taking second or third and subsequent attempts is higher for overseas students than for UK candidates, and particularly so for those from the Indian Sub-Continent (Table III). Pass rates tend to fall with later attempts, particularly with the UK/Eire candidates (Table IV).

TABLE III

Number of attempts by British and Overseas candidates

\begin{tabular}{|c|c|c|}
\hline $\begin{array}{l}\text { No. of } \\
\text { candi- } \\
\text { dates }\end{array}$ & $\begin{array}{c}\text { lst } \\
\text { attpt. }\end{array}$ & $\begin{array}{l}\text { 2nd } \\
\text { attpt. }\end{array}$ \\
\hline
\end{tabular}

\begin{tabular}{lrrrr}
$\begin{array}{l}\text { A. Preliminary Test: } \\
\text { September 1984 }\end{array}$ & & & & \\
UK/Eire & 191 & $80 \%$ & $14 \%$ & $6 \%$ \\
Indian sub-Continent & 114 & $42 \%$ & $28 \%$ & $30 \%$ \\
$\begin{array}{l}\text { Other countries } \\
\text { B. Membership Examination: }\end{array}$ & 63 & $54 \%$ & $14 \%$ & $32 \%$ \\
November 1984 & & & & \\
UK/Eire & 198 & $73 \%$ & $14 \%$ & $14 \%$ \\
Indian sub-Continent & 97 & $39 \%$ & $29 \%$ & $32 \%$ \\
Other countries & 67 & $48 \%$ & $27 \%$ & $25 \%$ \\
& & & & \\
\hline
\end{tabular}

TABLE IV

Pass rates for first, second and subsequent attempts

\begin{tabular}{|c|c|c|c|c|}
\hline & $\begin{array}{c}\text { 1st } \\
\mathrm{n} \text { (Pass) }\end{array}$ & $\begin{array}{l}\text { ttempts: } \\
\text { 2nd } \\
\text { n(Pass) }\end{array}$ & \multicolumn{2}{|c|}{$\begin{array}{c}\text { 3rd or more } \\
\text { n(Pass) }\end{array}$} \\
\hline \multicolumn{5}{|l|}{ A. Preliminary Test: } \\
\hline \multicolumn{5}{|l|}{ September 1984} \\
\hline UK/Eire & $153(70 \%)$ & $26(54 \%)$ & \multicolumn{2}{|c|}{$12(50 \%)$} \\
\hline \multicolumn{5}{|l|}{ Indian } \\
\hline Sub-Continent & $48(27 \%)$ & $32(6 \%)$ & \multicolumn{2}{|c|}{$34(18 \%)$} \\
\hline Other countries & $34(41 \%)$ & $9(40 \%)$ & \multicolumn{2}{|c|}{$20(15 \%)$} \\
\hline \multicolumn{5}{|l|}{ B. Membership } \\
\hline \multicolumn{5}{|l|}{ Examination: } \\
\hline \multicolumn{5}{|l|}{ November 1984} \\
\hline UK/Eire & $169(73 \%)$ & $21(48 \%)$ & \multicolumn{2}{|c|}{$8(13 \%)$} \\
\hline \multicolumn{5}{|l|}{ Indian } \\
\hline Sub-Continent & $37(32 \%)$ & $31(32 \%)$ & \multicolumn{2}{|c|}{$29(17 \%)$} \\
\hline Other countries & $32(53 \%)$ & $18(33 \%)$ & \multicolumn{2}{|c|}{$17(24 \%)$} \\
\hline \multirow{2}{*}{\multicolumn{5}{|c|}{$\begin{array}{c}\text { TABLE V } \\
\text { Number of attempts at Preliminary Test of candidates for Member- } \\
\text { ship Examination, November } 1984\end{array}$}} \\
\hline & & & & \\
\hline & \multirow{2}{*}{$\begin{array}{l}\text { Number of } \\
\text { candidates }\end{array}$} & \multicolumn{3}{|c|}{ Attempts: } \\
\hline & & 1 & 2 & $\begin{array}{l}3 \text { or } \\
\text { more }\end{array}$ \\
\hline UK & 198 & $85 \%$ & $11 \%$ & $4 \%$ \\
\hline Indian Sub-Continent & 97 & $38 \%$ & $32 \%$ & $30 \%$ \\
\hline Other countries & 67 & $48 \%$ & $27 \%$ & $25 \%$ \\
\hline
\end{tabular}

TABLE VI

Pass rate in Membership Examination according to number of attempts at Preliminary Text

\begin{tabular}{lrrrrrr}
\hline & \multicolumn{5}{c}{ Attempts at Preliminary Test: } \\
& & 1 & & 2 & 3 & 3 or more \\
& & & & & & \\
\cline { 2 - 7 } & n & Pass & n & Pass & n & Pass \\
\hline UK & 169 & $73 \%$ & 21 & $48 \%$ & 8 & $13 \%$ \\
Indian Sub-Continent & 37 & $32 \%$ & 31 & $32 \%$ & 29 & $17 \%$ \\
Other countries & 32 & $53 \%$ & 18 & $33 \%$ & 17 & $24 \%$ \\
\hline
\end{tabular}

Number of attempts at Preliminary Test for Membership Examination candidates

In the Membership Examination candidates from overseas had a history of one or more failures in the Preliminary Test more commonly than UK graduates (Table V). Again the 'other countries' group occupied an intermediate position between UK and Indian graduates. As would be expected there is an association between success in the Membership Examination and earlier success in the Preliminary Test, though this is less apparent for overseas than for UK graduates (Table VI).

Reasons for failure: Preliminary Test

Overall, $64 \%$ of those who failed did so in both papers, $24 \%$ on the 'multiple choice question' paper alone and $12 \%$ on the essay paper alone. These percentages differ between the three sub-groups (Table VII) only to a small extent. UK/Eire candidates who fail tend to do worse in the MCQ paper than in the essay, but there is no evidence that overseas candidates perform strikingly worse in either part.

Reasons for failure: Membership Examination

Only $17 \%$ of unsuccessful candidates in the Membership Examination failed in one part only (Table VIIIa). Among these, the MCQ and the clinical were the most frequent causes of failure. Differences between the three groups are small. Analyis of larger numbers would be necessary for reliable inferences.

Sixty-one per cent of candidates failed in one or two parts of the examination and $39 \%$ in three or four parts (Table VIIIb). Those who failed did so more completely among the overseas candidates than in the UK/Eire sub-group. Table VIIIc shows the failure rates in each component of the examination for the 171 candidates who failed overall. Failed candidates in each of the three subgroups performed equally badly in the MCQ paper. Overseas candidates were more likely to have failed in the other parts, particularly the essay paper and the clinical.

\section{Cohort studies: Membership Examination}

I am indebted to Dr Christine Hassall for providing data relating to successive cohorts of candidates for the Membership Examination. In what follows, candidates from the 
TABLE VII

Preliminary Test: Reasons for faihure

\begin{tabular}{lcccc}
\hline & $\begin{array}{c}\text { Number of } \\
\text { candidates } \\
\text { who failed }\end{array}$ & $\begin{array}{c}\text { Failed } \\
\text { in } \\
\text { both papers }\end{array}$ & $\begin{array}{c}\text { Failed only } \\
\text { in } \\
\text { MCQ }\end{array}$ & $\begin{array}{c}\text { Failed only } \\
\text { in } \\
\text { essay }\end{array}$ \\
\hline All candidates & 201 & $129(64 \%)$ & $48(24 \%)$ & $24(12 \%)$ \\
UK/Eire & 64 & $36(56 \%)$ & $22(34 \%)$ & $6(10 \%)$ \\
Indian Sub-Continent & 93 & $66(71 \%)$ & $17(18 \%)$ & $10(11 \%)$ \\
Other countries & 44 & $27(61 \%)$ & $9(20 \%)$ & $8(18 \%)$ \\
\hline
\end{tabular}

TABLE VIII

Reasons for failure: Membership Examinations

\begin{tabular}{|c|c|c|c|c|c|c|}
\hline \multicolumn{7}{|c|}{ A. Candidates who failed in one part only } \\
\hline & \multirow{2}{*}{$\begin{array}{l}\text { No. of } \\
\text { candidates } \\
\text { who failed }\end{array}$} & \multirow{2}{*}{$\begin{array}{l}\text { No. who } \\
\text { failed in } \\
\text { one part } \\
\text { only }\end{array}$} & \multicolumn{4}{|c|}{ Failed only in: } \\
\hline & & & MCQ & Essay & Clinical & Oral \\
\hline All candidates & 171 & $29(17 \%)$ & 12 & 2 & 14 & 1 \\
\hline UK/Eire & 63 & $12(19 \%)$ & 4 & - & 8 & - \\
\hline Indian Sub-Continent & 70 & $10(14 \%)$ & 6 & 1 & 3 & - \\
\hline Other countries & 38 & $7(18 \%)$ & 2 & 1 & 3 & 1 \\
\hline
\end{tabular}

B. Number of parts in which candidates failed

\begin{tabular}{lccc}
\hline & $\begin{array}{c}\text { No. of } \\
\text { candidates } \\
\text { who failed }\end{array}$ & 1 or 2 parts & Percentage who failed in: \\
& 171 & 61 & 39 \\
All candidates & 63 & 71 & 29 \\
UK/Eire & 70 & 54 & 46 \\
Indian Sub-Continent & 38 & 58 & 42 \\
Other countries & & & \\
\hline
\end{tabular}

C. Failure rates in each part of Examination for candidates who failed overall

\begin{tabular}{lccccc}
\hline & $\begin{array}{c}\text { No. of } \\
\text { candidates } \\
\text { who failed }\end{array}$ & MCQ & $\begin{array}{c}\text { Percentage who failed in: } \\
\text { Essay }\end{array}$ & Clinical & Oral \\
\hline All candidates & 171 & 70 & 65 & 58 & 40 \\
UK/Eire & 63 & 71 & 59 & 51 & 37 \\
Indian Sub-Continent & 70 & 71 & 67 & 63 & 46 \\
Other countries & 38 & 66 & 74 & 61 & 37 \\
\hline
\end{tabular}


TABLE IX

Membership Examination: Follow-up of cohorts

\begin{tabular}{|c|c|c|c|c|c|}
\hline & \multirow[b]{2}{*}{$\mathfrak{n}$} & \multicolumn{4}{|c|}{ Outcome by 1983} \\
\hline & & $\begin{array}{l}\text { Pass at } \\
\text { first } \\
\text { attempt }\end{array}$ & $\begin{array}{c}\text { Pass } \\
\text { eventually }\end{array}$ & $\begin{array}{l}\text { Drop out } \\
\text { before fifth } \\
\text { attempt }\end{array}$ & $\begin{array}{c}\text { Fail at } \\
\text { fifth } \\
\text { attempt }\end{array}$ \\
\hline \multicolumn{6}{|c|}{$\begin{array}{l}\text { A. Cohort of November } 1974 \\
\text { to November } 1976(n=606)\end{array}$} \\
\hline UK/Eire & 415 & $60 \%$ & $95 \%$ & $4 \%$ & $<1 \%$ \\
\hline Indian/Arab & 139 & $35 \%$ & $75 \%$ & $18 \%$ & $7 \%$ \\
\hline Other countries & 52 & $44 \%$ & $81 \%$ & $17 \%$ & $2 \%$ \\
\hline \multicolumn{6}{|c|}{$\begin{array}{l}\text { B. Cohort of May } 1977 \\
\text { to May } 1979(n=651)\end{array}$} \\
\hline UK/Eire & 440 & $74 \%$ & $95 \%$ & $4 \%$ & $<1 \%$ \\
\hline Indian/Arab & 156 & $26 \%$ & $81 \%$ & $15 \%$ & $4 \%$ \\
\hline Other countries & 55 & $45 \%$ & $84 \%$ & $13 \%$ & $4 \%$ \\
\hline
\end{tabular}

Indian Sub-Continent are grouped with those who qualified in the United Arab Republic.

Candidates are allowed five attempts at the Membership Examination. If they do not pass in five years they are required to re-sit the Preliminary Test. Thus if we go back a few years and identify a cohort of those taking the examination for the first time during a given period, we can follow their subsequent fate. Table IX shows the outcome of events, as reviewed in 1983, among two cohorts each comprising all those who took the Membership Examination for the first time over a two-year period in the 1970s. For each of these cohorts the ultimate pass rate for UK candidates was $95 \%$, and for Indian/Arab candidates $75 \%-81 \%$, with others from overseas taking the intermediate position of $81-84 \%$. From the data in Table IX, it is striking that considerable numbers of overseas candidates dropped out without making the five attempts allowed. Numbers who proceeded to a fifth attempt were correspondingly small.

\section{Summary}

(1) Overseas candidates do considerably less well in the College examinations than those from UK and Eire.

(2) Candidates who graduated in medicine in the Indian Sub-Continent fare worse than those from other countries.

(3) These discrepancies are consistent through both parts of the Preliminary Test and all four parts of the Membership Examination.

(4) It is not possible to pinpoint specific causes of failure. The MCQs are not specifically to blame, nor are the essays; nor, in the Membership Examination, is the clinical.

(5) Cohort studies of the Membership Examination show that up to $18 \%$ of candidates from overseas (compared with $5 \%$ of those from UK) drop out before the fifth attempt.

\section{Increasing pass rates}

Pass rates in a professional examination may be increased in the following ways (for all candidates or a subgroup): (1) More appropriate selection of trainees; (2) Early identification of those not suited; (3) Improve education, training, etc; (4) Review the examination-(i) Validity of the component parts and of the balance between them; (ii) Reliability (consistency of examiners); (iii) Are the standards appropriate?; and (iv) Minimise causes of 'accidental' failure.

\section{Comments}

(1) With any examination, in any country, indigenous candidates do better, as a group, than those coming from other countries. This is to be expected.

(2) The Royal College of Psychiatrists is a UK College, not an international body. It is not right to say, as I have heard it said, that the examination is specifically geared to UK graduates. But it has to take its bearings from UK practice. It has to be expected that a successful candidate in the MRCPsych would, after a period of approved higher training, be a suitable person for appointment as a consultant psychiatrist in the UK.

\section{REFERENCE}

${ }^{1}$ HASSALL, C. \& TREThOWAN, W. H. (1974) Analysis of the results of the three examinations for the Membership. News and Notes (supplement to the British Journal of Psychiatry), April, 2-4. 